12. Kukhnjuk D.V. Spotvorena chesnistj [Distorted honesty] // JuRLIGhA 24.04 2019. URL: https://jurliga.ligazakon net/experts/265/873 spotvorena-chesnst (in Ukrainian).

13. Kuxnyuk Dmy'tro. Advokats'ka ety'ka v Ukrayini - Zvit [Law Ethics in Ukraine - Report ]. Laboratoriya zakonodavchy'x iniciaty'v. 2018. URL: http://parlament.org.ua/wp-content/uploads/2019/01/report.pdf (in Ukrainian) (in Ukrainian)

14. Pravy'la advokats'koyi ety'ky' zatverdzheni Zvitno-vy'borny'm z'yizdom advokativ Ukrayiny' vid 9 chervnya 2017 roku. [The rules of lawyer's ethics were approved by the Reporting and Election Congress of Lawyers of
Ukraine dated June 9, 2017.]. URL: http://unba. org.ua/assets/uploads/ legislation/pravila/2017-06-09-pravila-2017 596f00dda53cd.pdf (in Ukrainian).

15. Prykladna etyka. Navch. posib. [Applied ethics. Teaching manual] / [Abolina T. Gh., Napadysta V. Gh., Rykhlicjka O. D. ta in.]; za nauk. red. Panchenko V. I. K. [Kyiv]: "Centr uchbovoji literatury", 2012. 392 s.

16. Tavartkiladze N.M. Ety'chni osnovy' diyal'nosti advokatazaxy'sny'ka [Ethical basis of the activity of the lawyer-defender]: avtoref. dy's....kand. yury'd. nauk. Odesa, 2003. 20 s. (in Ukrainian).

Received: $20 / 05 / 2019$

1sr revision: 22/09/2019

Accepted: 20/11/2019

D. Kukhnyuk, PhD. (Law), Associate prof.,

B. Shylenko, PhD. (Philosophy)

Taras Shevchenko National University of Kyiv, Kyiv, Ukraine

\title{
DISCIPLINARY LIABILITY FOR VIOLATION OF LEGAL ETHICS
}

The article is devoted to the research of legal ethics and disciplinary liability of the lawyer for their violation, the necessity and expediency of such liability. It has been discovered that the legal community is a part of the modern Ukrainian society, which stands guard over the protection of its interests. The appropriate constitutional status and responsibilities imposed on the advocacy cause the society's acute attention to the moral and ethical component of the activity of the advocacy in general and each lawyer in particular. It concerns both daily activities in real life and legal activities in social networks, which have become a significant part of our reality due to their total dissemination in personal and professional life of the individual.

Such increased public attention to advocacy determines the need to ensure appropriate quality control over the specified professional activity, which is carried out by specialized structural divisions of the advocacy as an autonomous and self-governing institute in Ukraine. The results of such control are the disciplinary liability of the lawyer.

The definition of disciplinary liability of a lawyer is a special type of legal liability applicable to a lawyer based on the results of a disciplinary proceeding carried out by a qualification and disciplinary commission of the advocacy for committing a disciplinary offensce.

The content of the Legal Ethics Rules has been researched and found to be rather extensive and contains only imperative obligations and prohibitions but does not contain specific guidance on the use of clearly defined sanctions for violation of a particular Rule. And the adherence of the lawyer to the Rules of Legal Ethics, the admissibility of their actions and statements in real life, as well as their activities in social networks are is determined on the basis of appraisal concepts and depends on the discretion of the authorities with the right of official interpretation of the Rules of Legal Ethics in the process of disciplinary proceedings and, as a result, disciplinary penalties.

Keywords: legal ethics, a lawyer, disciplinary liability, social networks.

Bulletin of Taras Shevchenko National University of Kyiv Legal Studies, 2019; 4 (111): 35-39

УдК: 343.1

DOI: https:doi.org/10.17721/1728-2195/2019/4.111-7
ISSN 1728-2195

C) Taras Shevchenko National University of Kyiv, Publishing center "Kyiv University", 2019

О. Оверчук, асп.

ORCID ID: 0000-0003-3959-9201

Київський національний університет імені Тараса Шевченка, Київ, Україна

\section{МЕТОДОЛОГІЧНІ ОСНОВИ ДОСЛІДЖЕННЯ МЕХАНІЗМУ ПРАВОТВОРЧОСТІ УНІТАРНОÏ ДЕРЖАВИ}

Досліджено сутність і роль методології у становленні правової системи України в правотворчому мехінізмі. Акцентовано увагу на проблемних підходах до визначення методологічних основ правотворчого механізму. Проаналізовано поточний стан правотворчості в Україні та внесення пропозицій з урахуванням методології права. Досліджено поняття методології, на підставі якого визначено основи методології правотворчості. На думку автора, методологія досліджень правотворчості має висвітлювати аналіз наукових підходів і застосування власних методів, що дозволить визначити найсуттєвіші характеристики цього правового явища, виокремити структурні елементи, указати на способи та шляхи найбільш результативної підготовки та прийняття нормативно-правових актів. Нині такими підходами можна вважати діалектичний, феноменологічний і герменевтичний цивілізаційні методи. Науковий пошук теоретико-методологічного засобу розгляду й розв'язання завдань правотворчості здійснювався та здійснюється в межах юридичного позитивізму - погляду на право як на сукупність норм, що встановлені та санкціоновані державою, за порушення яких застосовуються заходи державного примусу. Це передбачає неприйняття метафізичного аспекту, пов'язаного з розкриттям сутності правових явищ, обмеженості предмета пізнання лише фактичним знанням. Розглянуто проблему конкретизації як юридичного феномена.

У иентрі авторського дослідження - методи, що застосовуються до дослідження конкретизації правотворчості. Автор доходить висновку, що вибір певного методу в процесі конкретизації сприятиме вдосконаленню даного процесу як важливого правового явища й наприкінці, підсумовуючи виклад матеріалу, дозволить удосконалити правотворчий процес у сучасному законодавстві.

Ключові слова: правотворчість, нормотворчість, законотворчість, правотворчий механізм, методологія, правотворчі органи.

\section{ВСТУП}

Методологія правотворчості вимагає початкового визначення, у яких аспектах говорити про правотворчість і що розуміти під правотворчістю органів виконавчої влади. 3 безлічі проблем правотворчості виберемо найзагальніші, які залежать від конкретної правової ситуації в органах виконавчої влади, проявилися за останні десятиліття найбільшою мірою і розв'язання яких проглядається на шляху використання нормотворчості. Це проблема зростання кількості нормативних правових актів, які містять значною мірою матеріальні та процесуальні адміністративні норми права. Пошук нових методологічних підходів до правотворчості проводиться в більш вузькому підході - нормотворчості, і під нормотворчістю органів виконавчої влади ми будемо розуміти процес створення правового механізму 
реалізації законів шляхом розробки акту застосування, внесення змін або скасування нормативних правових актів органів виконавчої влади. Щоб точніше визначити методологію правотворчості, розкриємо динаміку розвитку проблем правотворчості.

Аналіз останніх досліджень і публікацій. Значний внесок щодо розробки цієї проблематики зробили науковці С. С. Алєксєєв, Ж. О. Дзейко, Д. А. Керимов, В. В. Копєйчиков, В. В. Лазарєв, М. М. Марченко та ін.

Метою статті $€$ проаналізувати та внести пропозиції для створення ефективного механізму державноправового захисту конституційних прав і свобод громадян та призупинення тенденції необґрунтованого зростання чисельності законодавчих актів.

\section{ВИКЛАД ОСНОВНОГО МАТЕРІАЛУ}

Правова природа методології юридичної науки. Предметом методології $€$ вивчення саме тих методів, засобів і прийомів, за допомогою яких набуваються та обґрунтовуються нові знання в науці. Зазначене дає змогу виокремити в методології як науці динамічний i статичний аспекти аналізу. Динамічний аспект взаємопов'язаний з аналізом проблем генезису, походження, становлення та розвитку наукового знання, що дає можливість говорити про методологію як наукове дослідження, що зорієнтоване на здобуток нового пізнання.

Статичний аспект методології зорієнтовано на вивчення та аналіз результатів отриманого знання, його форм і структур. У цьому випадку йдеться про методологію існуючого знання як результат попереднього дослідження.

На думку профресора М.І. Козюбри, який звертає увагу на багаторівневий характер методології, аналізуючи методологію з фрілософського погляду як методологію вищого рівня узагальнення, яка становить світоглядну основу всієї наукової діяльності, та конкретні (спеціальні, приватні) рівні методологічного осмислення даних науки та практики, що становить систему дослідницьких принципів і методів спеціальних наук, а також вчення про цю систему. [4, 22].

Методологія юридичного пізнання, як і методологія правової науки загалом, розглядається неоднозначно.

Поняття методології, та й сама вона неодноразово ставали предметом наукового аналізу, однак досі немає однозначності розуміння цього питання.

"Методологія права $€$ не що інше, як загальнонауковий феномен, об'єднує всю сукупність принципів, засобів і методів пізнання (світогляд, фрілософрські методи пізнання і вчення про них, загально- і приватнонаукові поняття і методи), вироблених усіма суспільними науками, в тому числі й комплексом юридичних наук, і застосовуються в процесі пізнання специфіки правової дійсності, її практичного перетворення" [2, 30].

Ототожнення методології із системою методів означає суто прагматичний підхід до розкриття даного поняття. При такому трактуванні методології на другий план відступають її світоглядне значення, фрілософрський зміст, неминуче принижується значення діалектичного матеріалізму, який є загальною науковою методологією саме тому, що діалектична логіка є суб'єктивним відображенням загальних об'єктивних законів руху й розвитку реального світу. Методологія $є$ єдиною органічною системою, яка виступає у вигляді своєрідного зводу законів наукового пізнання $[4,28]$.

Можна визначити такі риси методології:

По-перше, поняття методології за обсягом не збігається з поняттям методу. Співвідношення методології та методу може бути представлене як діалектична єдність цілого й частини, системи й елемента, загального й окремого.

По-друге, методологія - це невід'ємна частина будьякої науки, при цьому її не слід змішувати і ототожнювати із самою наукою. Методологія $€$ інструментом, засобом науки; з іншого боку, вона ширше будь-якої конкретної науки, оскільки може мати міждисциплінарний і загальнонауковий характер.

По-третє, методологія не вичерпується самим вченням і методами пізнання, сюди входять також інші явища: світогляд, принципи, поняття та категорії тощо. Даний перелік на сьогодні можна залишити відкритим, оскільки він залежить від сорери застосування методології.

По-четверте, складові компоненти методології мають інтегративний характер, тісно взаємодіють і становлять систему. Серед елементів даної системи провідне місце займають методи, що застосовуються дослідником, принципи та основні категорії; саме вчення про метод або методи, що застосовуються тією чи іншою наукою, виступає як інтегруюче даної системи.

По-п'яте, в методології, на підставі прогнозованих результатів, умовно можна виділити три напрями: спеціальний, міждисциплінарний і загальнонауковий. Кожен зазначений напрям характеризується відносно самостійним інструментом. Разом із тим ці напрями реалізуються в комплексі, оскільки не можна отримати відносно адекватний результат (об'єктивні знання про предмет дослідження) без реалізації всіх напрямів методологічного впливу на досліджувану реальність.

По-шосте, зміст методології залежить від рівня пізнання. Теоретичному рівню властиві принципи, методи, категорії, що спрямовані на створення абстрактного уявлення досліджуваного явища, і на цій основі формуються напрями практичної реалізації теорії. Практичному рівню властиві елементи методології, що сприяють фріксації реальних властивостей предметів, які вивчаються, або явищ.

По-сьоме, зміст методології залежить і від суб'єктів пізнання. Чим компетентніше суб'єкт, тим різноманітнішим буде дослідний арсенал. Разом із тим чим менше вихідна база знань у суб'єкта, тим сміливіше він береться за важкорозв'язувані задачі й часто досягає успіху.

По-восьме, методологія є базисом будь-якого дослідження, тому що якість результату залежить від якості змісту застосовуваної методології. Це пов'язано з правильним вибором об'єкта і предмета дослідження, способів дослідження, послідовності їх застосування, адекватною інтерпретацією і фрормулюванням категорій і принципів.

По-дев'яте, методологія - це свого роду шлях до отримання істинного знання про об'єкт і предмет дослідження. Цей шлях складається із різних етапів. Логіко-гносеологічний аналіз даного явища дозволяє умовно виділити три етапи: початковий, наступний і завершальний. На початковому етапі формується первинне знання про об'єкт і застосовуються ті частини методології, які відповідальні за це (як правило, це елементи практичного рівня методології, наприклад такі методи, як спостереження, вимірювання, експеримент тощо). Наступний етап характеризується застосуванням аналітичної методології (формування робочих понять, суджень, аналіз і синтез тощо). На завершальному етапі формуються висновки дослідження, для чого використовуються фактично всі елементи методології, головне місце серед яких займають вчення i світогляд дослідника. 
По-десяте, методологія - це суб'єктивно-об'єктивний комплекс, який характеризується обґрунтуванням і впливом на будь-які об'єкти при здійсненні не тільки теоретичної, але і практичної діяльності.

Можна дійти таких висновків:

1. Методологія - це передусім певний теоретичний i емпіричний інструментарій (техніка), тобто сукупність засобів (загальносоціальних, технічних, спеціальноюридичних) пізнання правових явищ, процесів і станів.

2. Методологія включає відповідні до предмета ії дослідження прийоми, способи, правила і методи вмілого і грамотного використання відповідного базового (емпіричного і теоретичного) матеріалу, а також засобів пізнання (тактику).

3. Юридична політика, наукові та емпіричні принципи, способи довгострокового планування і прогнозування досліджень, що визначають перспективу розвитку фундаментальної та інших юридичних наук, утворюють у методології її стратегічний компонент.

4. У методологію входять методика узагальнення, систематизації й обробки отриманих знань, формулювання наукових висновків і рекомендацій, процедури їх упровадження в різноманітні юридичні науки, навчальні та виховні процеси, практики перетворення відповідних сфер життєдіяльності суспільства.

5. Важливим компонентом методології $€$ світоглядна основа науки - система певних життєвих позицій вчених-юристів, їхні ідеали і переконання, ціннісні орієнтири й настанови, які відіграють істотну роль у науковому дослідженні та практичній діяльності.

6. Методологія $є$ вченням про техніку, тактику, стратегію, методику пізнання реальної дійсності, будову наукового знання і найперспективніші шляхи та напрями наукового пошуку [4, 32].

Усі зазначені вище компоненти (аспекти, зв'язки) становлять логічну структуру методології юридичних наук.

Визначаючи методологічні основи правотворчості, не слід ії ототожнювати 3 методами наукових досліджень, хоча між ними існує тісний взаємозв'язок, що базується на єдності пізнавальної, пояснювальної, евристичної та прогностичної функцій, а також функції забезпечення практичної реалізації наукових досліджень і заснованих на них рекомендацій.

Методологія як система не зводиться до складників, вона має й відносно самостійні власні інтегративні закономірності розвитку. Ці закономірності обумовлюються тим, що компоненти методології, будучи об'єднаними в органічно цілісну систему, виступають спільно, об'єднуючи відносини і взаємодії між собою, тим самим набуваючи відмінних властивостей від їхнього єдиного існування та дії.

На підставі викладеного методологію правотворчості можна визначити як систему елементів, що становлять теоретичну основу, і засоби дослідження в галузі юриспруденції, а також систему способів практичного впливу на суспільні відносини у сфері дії права.

Основні напрями методології правотворчості. У методиці вивчення правотворчості можна виділити три основні напрями. Першій - сукупність прийомів вивчення об'єктивних умов, якими визначаються цілі, зміст і засоби зміни в законодавстві. Можна сказати, що цей напрям пов'язаний переважно із вивченням зовнішнього середовища - соціальних факторів правотворчості та об'єктів правового регулювання. Другий напрям - сукупність прийомів вивчення власне процесу правотворчості, тобто правотворчої діяльності, організації правотворчості, її процесуального порядку, які регла- ментують саму правотворчу діяльність і порядок ії здійснення. Третій напрям - розробка процедур дослідження правотворчості, його методів і методик.

Правотворчість як соціально-регулятивна діяльність у соціологічному аспекті нещодавно не привертала особливої уваги. Можна припустити, що правотворчу діяльність, здійснювану кваліфікованими юристами, психологічно важко досліджувати як самостійний об'єкт. Тому інтенсивний науковий аналіз процесу правотворчості на теоретичному і соціально-правовому (емпіричному) рівнях проводиться порівняно недавно. Звідси виникає й завдання більш розширеної розробки методики емпіричних досліджень у цій галузі, визначають низку питань, що підлягають розв'язанню.

Перше $з$ них пов'язане з виявленням специфіки методики дослідження правотворчості порівняно з методиками дослідження інших соціально-регулятивних процесів. Певні особливості тут обумовлені, очевидно, характером об'єкта вивчення, зокрема показниками стану правотворчості в кримінальному праві, які відображають його сутнісні риси, рівень, тенденції тощо. Специфічною можна вважати й оцінку значення інформації про правотворчість, шляхи її використання для отримання різних висновків, у тому числі для цілей як приклад.

Теоретики права і фрахівці в галузі методології соціально-правових досліджень розглядають правотворчій процес як специфічний об'єкт пізнання. Наприклад, Н. В. Теремцова у своїх працях зазначає, що соціальний механізм правотворчої діяльності $\epsilon$ функціональною системою - об'єктом дослідження соціології права, стосовно якого можуть бути застосовані поняття і методи структурно-фрункціонального аналізу [5, 16].

До досліджень, суттєвих для процесу правотворчості, слід віднести також вивчення закономірностей функціонування законодавства. Тут потрібно відзначити зміни законодавства і його тенденції, виявлення кількості та часового розподілу змін у законі, аналіз характеру цих змін тощо.

Тривалий час у теорії права існували два методологічні підходи до дослідження природи права, які ґрунтувались на виключно односторонньому аналізі розуміння змісту права. Перший із них полягає в прихильності до проголошеного у XX столітті позитивістського ототожнення права й закону, аналізу змісту права в повній залежності від державної волі, що зводить право до наказу держави. Такий підхід поширений досі й залишається поза увагою розгляд права як засобу втілення в життя справедливості, гуманності як необхідних складових демократичного розвитку суспільства, обмежує юридичну науку лише дослідженням догми права, перетворенням правознавства на законознавство. Наслідком такого праворозуміння $€$ недооцінювання соціальної природи джерел права.

Інший підхід полягає у зведенні права виключно до природних прав людини, обґрунтуванні неналежності та необов'язковості їх відображення в законодавстві, запереченні або недооцінюванні та впливу державної влади на правоутворення і правореалізацію. Недооцінювання ролі держави у правовому регулюванні суспільних відносин, урешті-решт, призводить до порушень закону, правового нігілізму тощо.

На думку автора, методологія досліджень правотворчості має охоплювати аналіз наукових підходів і застосування власних методів, що дозволить визначити найсуттєвіші характеристики цього правового явища, виокремити структурні елементи, вказати на способи та шляхи найбільш результативної підготовки та прийнят- 
тя нормативно-правових актів. Сьогодні такими можна вважати діалектичний, френоменологічний, герменевтичний цивілізаційні методи.

Використання діалектичного методу надає можливість акцентувати увагу не тільки на виявленні особливостей і визначенні поняття джерел права, а й на зв'язку цього явища з іншими явищами, інститутами, процесами [4, 30].

Феноменологічний підхід у дослідженні права дає змогу уявити зміст права у вигляді певного правового феномена, який у поєднанні з моральними принципами й цінностями, правовою спадщиною, принципами гуманізму зумовлює децентралізацію права, зближення природного та позитивного права, сприяє відкритості правових систем.

Герменевтичний підхід до вивчення джерел права надає можливість уявити їх у вигляді взаємодії суб'єктів суспільних відносин із приводу створення норм права, що зводиться до розумово-речової діяльності. Така суспільна взаємодія має структуру, яка, по суті, є структурою суспільних відносин, що, у свою чергу, мають вигляд суспільно-інформаційних процесів. Уся правотворча діяльність та її результати уявляються у вигляді структурної інформаційно-речової взаємодії.

Цивілізаційний підхід дає змогу визнати природним розмаїття правових культур і державних інститутів як мозаїку світу, що розвивається, зберегти власну унікальність, використати досягнення різних цивілізацій, вести з ними культурний діалог, знаходити спільні правові рішення й організаційні засоби їх здійснення під час взаємодії з іншими правовими системами та державами.

Проблеми правотворчого механізму. На практиці основною проблемою правотворчого механізму є безліч нормативно-правових актів, які потребують кодифікації. Для подолання даної проблеми необхідно дослідити проблеми в механізмі правотворчості через призму методологічного пізнання. Методологія законотворчого пізнання полягає в тому, що органи виконавчої влади та їхні посадові особи зобов'язані визначити методику пізнання. Першим етапом правотворчого пізнання $€$ визначення таких суспільних відносин, які підлягають регулюванню; другим - визначення сприятливих умов для розвитку суспільних відносин; третім етапом - досягнення корисного ефективного припису норми права.

Підготовка нормативних правових актів органами виконавчої влади та їхніми посадовими особами відбувається у формі концепції, планування, законодавчої ініціативи, попереднього розгляду проекту нормативноправового акта, правової експертизи, підписання та набуття законної сили нормативного правового акта.

Методика проведення кодифікації як вид систематизації нормативних правових актів органами виконавчої влади - це вираження норм права, що містяться в систематизованих нормативно-правових актах, в одному новому нормативно-правовому акті, прийняття якого позбавляє чинності раніше прийняті нормативно-правові акти. Методологія проведення кодифікації заснована на принципах своєчасності, повноти, єдиної спрямованості.

Таким чином, органи виконавчої влади, їхні посадові особи зобов'язані використовувати законодавчу техніку з метою створення ефективного механізму реалізації державно-правового захисту конституційних прав і свобод громадян.

Безумовно, науковий пошук теоретико-методологічного інструменту розгляду й розв'язання завдань правотворчості здійснювався і здійснюється в межах юридичного позитивізму - розгляду права як сукупності норм, установлених і санкціонованих державою, за порушення яких слідують заходи державного примусу. Це передбачає неприйняття метафізичного аспекту, пов'язаного з розкриттям сутності правових явищ, обмеженості предмета пізнання тільки фактичним знанням (розгляду права як закону). Юридичний позитивізм передбачає розкриття змісту права через його форму та втілення в нормативно-правові акти.

Методологія конкретизації правотворчості має включати, на наш погляд, і теоретичні, і практичні моменти щодо приділення особливої уваги до юридичної техніки, особливо в умовах розвитку порівняльного правознавства, гармонізації внутрішньодержавного і міжнародного права. У процесі конкретизації часто формулюються юридичні терміни, юридичні конструкції, уніфрікується правова термінологія, усуваються законотворчі помилки, виключаються непотрібні повторення тощо.

У процесі правотворчої конкретизації застосовуються:

- логічні методи (вихідного від абстрактного до конкретного, логічний, аналіз, синтез, індукція, дедукція, абстрагування, аналогія);

- методи теоретичного, у тому числі приватного наукового дослідження (системний, герменевтичний, формально-юридичний, порівняльний та ін.).

Не останню роль відіграють і методи соціальних досліджень і синергетика. Усі ці види досліджень взаємопов'язані.

Слід сказати, що конкретизація в законотворчості знаходить вираз у діяльності спеціальних уповноважених органів, наділених нормотворчою компетенцією щодо переведення змісту юридичних норм від абстрактного до конкретного. Однак при детальнішому аналізі даної проблематики виникає питання стосовно суддівського активізму, у тому числі судової конкретизації.

Основне завдання конкретизації - досягти визначеності в праві. У ході конкретизації передбачається переробка змісту норми, на відміну від офріційного тлумачення права. Конкретизація служить розкриттю сенсу i змісту правових норм. Однак при конкретизації раніше виданої норми завжди передбачається більша або менша зміна ії змісту. I стає зрозумілим, що чинне законодавство дає безліч прикладів непорозуміння або свідомого ігнорування з боку законодавця логіки вже існуючих правових норм у процесі їх подальшої правотворчої конкретизації [5, 12]. У зв'язку з цим виникає питання щодо прийомів і методів наукового дослідження, які слід застосовувати в тій чи іншій ситуації (незрозумілості норми, "мовчання" законодавця тощо). Державноправовою гарантією від зловживання квазіконкретизацією (конкретизацією зі знаком мінус) є судова система 3 ії повноваженнями за нормоконтролем.

ВИСНОВКИ. Проблемам правотворчості приділяється багато уваги в юридичній літературі, але ж досконало вони не вивчені. Погляди на подолання проблем дуже суперечливі, тому вимагають подальшої розробки з урахуванням юридичної практики. Очевидно, що вибір того чи іншого методу в даному процесі буде сприяти вдосконаленню конкретизації та зменшенню нормативно-правових актів, що врешті-решт дозволить удосконалювати правотворчий процес.

Список використаних джерел:

1. Конституція України : офріц. текст. Київ : КМ, 2013. 96 с.

2. Дзейко Ж. О. Сучасний стан та пріоритетні напрямки розвитку законодавчої техніки в Україні: практичні аспекти / Ж. О. Дзейко // Університетські наукові записки. 2016. № 3-4. С. 28-35.

3. Теорія держави і права. Академічний курс : підруч. / О. В. Зайчук, А. П. Заєць, В. С. Журавський; Київ: Юрінком Інтер, 2008. С.28. 
4. М. Козюбра. Методологія правознавства і методологія права: співвідношення понять та їх особливості. Право України. 2014. С. 22-32

5. Теремцова Н.В. Основні підходи до розуміння юридичної відповідальності. Європейські перспективи. №1, 2017. С.12-17.

\section{References:}

1. Konstytutsiia Ukrainy: ofits. tekst. Kyiv: KM, 2013. 96 s. [in Ukrainian].

2. Dzeiko Zh. O.(2016). Suchasnyi stan ta priorytetni napriamky rozvytku zakonodavchoi tekhniky $v$ Ukraini: praktychni aspekty [Current state and priority directions of development of legislative technique in Ukraine: practical aspects]. Universytetski naukovi zapysky. - University Science Notes, 3-4, 28-35 [in Ukrainian].
3. O. V. Zaichuk, A. P. Zaiets, V. S. Zhuravskyi, 2008, Teoriia derzhavy prava. Akademichnyi kurs : pidruch. [The theory of state and law] Kiev: Urinkom inter [in Ukrainian].

4. M. Koziubra (2014) Metodolohiia pravoznavstva i metodolohiia prava: spivvidnoshennia poniat ta yikh osoblyvosti. [ Methodology of jurisprudence and methodology of law: correlation of concepts and their featuresn]. - Pravo Ukrainy - Law of Ukraine. [in Ukrainian]

5. Teremtsova N.V. (2017). Osnovni pidkhody do rozuminnia yurydychnoi vidpovidalnosti. [Basic approaches to understanding legal liability.]. Yevropeiski perspektyvy. - European perspective, 1, 12-17 [in Ukrainian].

Received: $28 / 11 / 2019$ 1st Revision: $12 / 12 / 2019$ Accepted: $15 / 01 / 2020$

O. Overchuk, PhD student

Taras Shevchenko National University of Kyiv, Kyiv, Ukraine

\section{METHODOLOGICAL BASES FOR THE RESEARCH ON THE MECHANISM FOR LAW-MAKING OF A UNITARY STATE}

The article deals with methodological bases for the of research on the mechanism for of law-making of a unitary state. The article is devoted to the study of the nature and role of methodology in the formation of the Ukraine's legal system during the law-making mechanism. Much attention is given to problematic approaches to determining methodological bases in law-making mechanism. The purpose of this article is to analyze the current state of lawmaking in Ukraine and to make proposals based on the methodology of law. The article explores the concept of methodology on the basis of which the methodological bases of lawmaking are determined. The author states that the methodology of research on lawmaking should cover the analysis of scientific approaches and application of own methods, which allow to identify the most essential characteristics of this legal phenomenon, to distinguish structural elements, to indicate the ways of the most effective preparation and adoption of legal acts. Law-making process is a form of the state activity intended for on the creation (or revision) of legal norms. The law-making process and the role of the legislative bodies in it are based on the constitutional principles of democracy, separation of powers, social state. Scientific search for a theoretical and methodological tool for considering and solving the problems of lawmaking is carried out within the framework of legal positivism - consideration of law as a set of norms established and sanctioned by the state, the violation of which is followed by measures of state coercion. This implies the rejection of the metaphysical side, related to the disclosure of the essence of legal phenomena. The problem of specification as a legal phenomenon is considered. At the heart of the author's research there are the methods used to investigate the elaboration of law-making. The author comes to a conclusion that the choice of a certain method in the course of a specification will promote the improvement of this process as an important legal phenomenon as well as the improvement of modern legislative process.

Keywords: law-making, rulemaking, law-making mechanism, methodology, law-making bodies.

Bulletin of Taras Shevchenko National University of Kyiv Legal Studies, 2019; 4 (111): 39-44

УДК: 347.962 .6

DOI: https:doi.org/10.17721/1728-2195/2019/4.111-8
ISSN 1728-2195

(C) Taras Shevchenko National University of Kyiv Publishing center "Kyiv University", 2019

О. Овчаренко, д-р юрид. наук, доц. Національний юридичний університет імені Ярослава Мудрого, Харків, Україна, Т. Подорожна, д-р юрид. наук, проф. ORCID 0000-0003-0502-950X Торговельно-економічний університет, Львів, Україна

\section{ВІДПОВІДАЛЬНІСТЬ СУДДІ ЗА ПОРУШЕННЯ ПРИПИСІВ КОНВЕНЦІЇ ПРО ЗАХИСТ ПРАВ ЛЮДИНИ ТА ОСНОВОПОЛОЖНИХ СВОБОД}

Досліджено проблеми відповідальності судді за порушення приписів Конвенції про захист прав людини і основоположних свобод. Зазначено, що в теорії права аксіоматичним є твердження, що за неправомірні дії посадових осіб відповідає держава незалежно від їхньої вини. Уповноважені органи держави в таких випадках можуть подати регресний позов у передбаченому законодавством порядку. При цьому спеціальною умовою відповідальності не є скасування незаконного рішення, яким була спричинена майнова шкода. Передумовою майнової відповідальності посадової особи $\epsilon$ ії вина. Зазначено, що майнова відповідальність судді за постановлення незаконних рішень, з огляду на його статус, має певні особливості. По-перше, за міжнародними стандартами, відшкодування суддею майнової шкоди за незаконне судове рішення, яким порушуються права і свободи людини та громадянина, тісно пов'язане з його процесуальною незалежністю й імунітетом. По-друге, установлюється не тільки компенсація державою збитків, що виникли внаслідок неправомірного рішення чи поведінки судді під час виконання його обов'язків, а й право держави на пред'явлення регресних вимог до судді, з вини якого завдано майнову шкоду фізичним або юридичним особам.

Ключові слова: права людини, практика ЄСпЛ, відповідальність судді, процесуальна незалежність судді, відшкодування шкоди, регресні вимоги, вина, професійні обов'язки, незаконне судове рішення.

ВСтУП. Сьогодні досить цікавим видається питання відповідальності держави й суддів як ії̈ представників за порушення зобов'язань, що випливають із Конвенції про захист прав людини і основоположних свобод. У теорії права аксіоматичним є твердження, що за неправомірні дії держави та її посадовців відповідає сама держава незалежно від вини цих посадових осіб, а вже потім вона вправі подати регресний позов у передбаченому законодавством порядку. При цьому спеціальною умовою відповідальності не $є$ скасування незаконного рішення, яким була спричинена майнова шкода. Передумовою майнової відповідальності посадової особи є її вина, на відміну від класичної концепції цивільно-правової відповідальності, що не зумовлена виною її суб'єкта.

Конституційний Суд України у Рішенні від 3 червня 2013 р. № 3-рп/2013 вказав, що "конституційні положення про незалежність суддів $€$ невід'ємним елементом статусу і професійної діяльності останніх і пов'язані з принципом поділу державної влади. Вони зумовлені 